\title{
Shadowing Technique To Improve Student's Listening Skill
}

\section{N.M.E. Junipisa ${ }^{1 *}$, I.N. Aristana ${ }^{2 *}$ (D) 1,2,3 Universitas Triatma Mulya, Indonesia}

\section{A R T I C L E I N F O}

Article history:

Received February 22, 2021

Revised February 25, 2021

Accepted June 17, 2021

Available online August 25, 2021

\section{Kata Kunci:}

Bahasa Inggris, Teknik

Membayangi, Keterampilan

Mendengarkan

Keywords:

English Language,

Shadowing Technique,

Listening Skil

DOI:

http://dx.doi.org/10.23887/jpbi.v 9i2.32516

\begin{abstract}
ABS TRAK
Kondisi yang terjadi di kelas adalah siswa merasa takut dengan bahasa Inggris. Siswa merasa bahwa belajar bahasa Inggris sulit untuk dihafal. Siswa mengalami kesulitan belajar karena guru tidak menerapkan model pembelajaran yang tepat kepada siswa. Hal ini menyebabkan siswa merasa bosan dalam belajar dan berdampak pada kemampuan Bahasa inggris siswa yang rendah. Tujuan penelitian ini yaitu untuk menganalisis menganalisis teknik shadowing dalam pembelajaran bahasa Inggris bagi mahasiswa. Jenis penelitian ini yaitu penelitian Tindakan kelas. Subjek penelitian yaitu 17 mahasiswa. Ada empat bagian utama dari penelitian tindakan kelas yaitu perencanaan, tindakan, observasi dan refleksi. Metode yang digunakan untuk mengumpulkan data yaitu observasi, wawancara, dan kuesioner. Teknik yang digunakan untuk menganalisis data yaitu analisis deskriptif kualitatif dan kuantitatif. Hasil penelitian yaitu nilai rata-rata, dari 73,2 pada siklus satu menjadi 76,0 pada siklus dua. Persentase siswa yang lulus KKM juga meningkat dari $59 \%$ menjadi $78 \%$. Keterampilan menyimak siswa meningkat setelah penerapan teknik shadowing. Dapat disimpulkan bahwa penerapan teknik shadowing dapat meningkatkan keterampilan menyimak siswa. Implikasi penelitian ini yaitu guru dapat menerapkan teknik shadowing didalam kelas. Penerapan teknik shadowing dapat menciptakan suasana belajar menjadi menyengkan bagai siswa sehingga meningkatkan kemampuan menyimak pada siswa.
\end{abstract}

\section{A B S T R A C T}

The condition that occurs in the classroom is that students are afraid of English. Students feel that learning English is difficult to memorize. Students have learning difficulties because the teacher does not apply a suitable learning model for students. This causes students to feel bored in learning and has an impact on students' low English skills. The purpose of this study is to analyze the shadowing technique in learning English for students. This type of research is classroom action research. The research subjects were 17 students. There are four main parts of classroom action research, namely planning, action, observation, and reflection. The methods used to collect data are observation, interviews, and questionnaires. The technique used to analyze the data is descriptive qualitative and quantitative analysis. The study results are the average value, from 73.2 in the first cycle to 76.0 in the second cycle. The percentage of students who passed the KKM also increased from 59\% to $78 \%$. Listening skills improve after the application of shadowing techniques. The key is that the application of shadowing techniques can improve students' listening. This research implies that teachers can apply shadowing techniques in the classroom. The application of shadowing techniques can create a fun learning atmosphere for students to improve students' listening skills.

This is an open-access article under the CC BY-SA license. Copyright (c) 2021 by Author. Published by Universitas Pendidikan Ganesha.

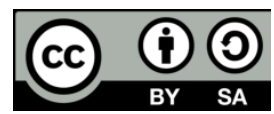

\section{INTRODUCTION}

In the current era of growing globalization, the role of communication is becoming increasingly important (Coffelt et al., 2019; Haji et al., 2017). The period of advances in science and technology has increasingly opened up international communication opportunities (Voorhees \& Vorobel, 2021; Wungguli \& Yahya, 2020). A language is a system for communicating our ideas and feelings, whether using sounds, gestures, signs, or marks (Dashtestani, 2013; Karimi \& Sanavi, 2014). A language is the written and spoken method of combining words to create meaning used by a particular group of people. English is a global language which essential to be mastered in this global era (Gjems, 2013; Khotimah et al., 2019; Muhammed, 2014). English is an international language used by many countries and is an international language (Chen et al., 2019; Liang et al., 2011). In the era of the industrial revolution, the use of English has become commonplace. That is why teaching English is very important to prepare English Learners as a Foreign Language to be competitive as the human resource in their life (Naghdipour, 2021; Tanihardjo, 2016).

The condition in class is that the students feel afraid of English as one of their subjects (Karimi \& Sanavi, 2014; Le \& Miller, 2020). They think that English is complicated (Alam \& Lestari, 2020; Rosmiati, 2019). So that, the student needs to focus on learning English. Previous research findings also stated that students find it 
challenging to learn. Students feel that learning English is difficult to memorize (Dwi et al., 2013; Megawati, 2016). English because they are lazy to learn foreign languages (Lestar, 2021; Surjono, 2016). Other research also states that students have difficulty comprehending because teachers do not apply appropriate learning models (Kurniawati et al., 2017; Mulyanah et al., 2018). This causes students to feel bored in learning (Alam \& Lestari, 2020; Dwi et al., 2013).

For that reason, the new technique in learning English is essential (Pratiwi et al., 2018; Surjono, 2016). The importance of the strategy used by the lecturer will improve students' skills in English (A. H. Lubis, 2018; Sihotang, 2019). To motivate the students, the lecturer needs to be a model and facilitator (Kaplan, 2018; Tjakradidjaja et al., 2016). It is necessary to apply the method in teaching English. In English, there are four language skills: listening, reading, reading, and writing (Karimi \& Sanavi, 2014; Le \& Miller, 2020). One of the essential skills that should be mastered is listening to skill. Listening is a crucial skill that must be learned in the language learning process (Amiryousefi \& Tavakoli, 2011; Nakanishi et al., 2019). Listening is the same as reading which is a receptive skill because both listening and reading focus on receiving information from an outside source. Listening is an active skill because listening is not only the process of hearing what speakers say but also integrating what the speakers talk about with the information in the real world (Jafari \& Hashim, 2012; Vu \& Shah, 2016). We can conclude that listening is one of the fundamental skills that the student in learning English should master.

In mastering English, there are so many methods or techniques that can be applied (Alilateh \& Widyantoro, 2019; Azar \& Nasiri, 2014). One of the techniques that can be used in teaching English is the Shadowing technique. The shadowing method improves interpreting skills (H. Liu \& Sammons, 2021; J. Liu \& Bray, 2020). The steps of the Shadowing Technique; a)concentrating on the correct pronunciation when shadowing the listening text,(b) attending to the meaning of the listening text, and (c) reproducing the listening text by picturing it (Chiu et al., 2020; Tum \& Kunt, 2021). The essence of the shadowing technique is that we learn a foreign language not only by imitating what other people say but also how to make body gestures and facial expressions when a sentence or phrase is spoken.

The findings of previous studies stated that there was an improvement in participants' English pronunciation, especially in English (H. Liu \& Sammons, 2021; J. Liu \& Bray, 2020). The findings of previous research also stated that the shadowing technique improves students' ability to speak English to be applied in learning (Gibbs \& Hilburn, 2021; Wardhana, 2018). There are no studies on shadowing techniques to improve students' listening skills. This study aims to analyze the shadowing approach in learning English. It is hoped that the shadowing strategy can help students improve their listening skills in English.

\section{METHOD}

The researcher used classroom action research called CAR as the research design. In this case, the researcher had improved the students' listening skills of Accounting Major in Triatma Mulya University. Classroom action research is research that is conducted in the classroom to solve problems during classroom activities. There are four main parts of classroom action research. They are; planning, action, observation, and reflection. Part one is planning. At this stage, everything needed in the teaching and learning process that will be carried out includes what, who, where, and how. The planning stage can be described as follows; Determine the research schedule, design learning activities (lesson plan), prepare teaching materials and prepare observation sheets and student worksheets (tests).

Part two is action. The researcher, as well as the lecturer, will take the following steps; Students are given a clue about the material to be delivered, students are divided into small groups and given the task to predict the contents of the lecture to be listened to (pre-listening study), students are allowed to listen to listening material through audiovisual, and each student is given a worksheet about the material they will hear (While-listening task), the students are divided into small groups to brainstorm on perceptions and interpretations of what they have listened to through the audiovisual media (Post listening task), in the final stages of students individually instructed to make a summary based on the results of interpretation and brainstorming in small groups. Part three is observation. At this stage, the researcher observes students' activeness in group discussions and the concentration and focus of students during listening activities with audiovisual media applied. Part three is reflection. In the final stage of this cycle, the researcher collects student work in worksheets and summaries. Then analyze the observation checklist and video recorder data to conclude the activities that occur in cycle 1 . Then the researcher will discuss the improvement of planning based on the results of the analysis of the observation checklist and student achievement in cycle one and design activities in cycle 2 when the indicators of success have not been achieved.

The technique of data collection that are applied in this research are 1) Observation. The researcher had used an observation checklist and field notes. The purpose of the observation was to know the activities during the teaching and learning process, such as how the lecturer explained the materials, what the students would respond 
to, and how the students have been worked in doing the test. 2) Test. The researcher also used tests to know the students' improvement in listening by using the shadowing technique. The researcher analyzed data using a checklist/observation sheet and field notes to describe the process of teaching and learning. Besides that, the researcher calculated the data of students' score listening skills by using a formula.

\section{RESULT AND DISCUSSION}

\section{Result}

In the first cycle, the researcher found that the mean score of the post-test in cycle one was 73.2, which means that the student who could pass the minimum criteria was 59 percent. That is why it was considered as unsuccessful. The activities done in the first cycle are classified as lecturer's activities, student's activities, and the last we can conclude those activities from the student's response.

The lecturer's activities in meeting one and meeting two are the same. He checked the attendance list and prepared everything that was needed. Then he explained the method of shadowing that would be applied in listening class. The steps were as follows; The lecturer asked the student to shadow the sentence in the listening test, which was repeated three times. The lecturer asked the student to write down what they were saying in the following, The lecturer asked them to find the meaning of the sentence they wrote in 5 minutes, and the lecturer checked the answer. The lecturer stood in front of the class and played and replayed the listening text. There was no time limitation when the student shadowed and wrote the sentence spoken by the second person in the listening text. He also did nothing if he saw that his student did not follow the second speaker's sentence as soon as they heard it. The teacher let the students shadow the sentence not as soon as they heard it, even though he initially instructed the student to follow it as soon as they heard it.

In meeting one and two of the student's activities, the students did the same things. The students shadowed the sentence, wrote down the sentence, found the meaning of the sentence, and discussed the answer. From the first meeting, the students felt afraid of making mistakes because they were not sure about what they heard, and also, this was the first time for them to learn with shadowing technique. The students seemed more comfortable in the next meeting because they already knew what to do in listening with the shadowing method. In cycle two, the students did the same thing. The lecturer will assist the students in doing the activities. The activities in cycle two have the same steps as cycle one, but the mean score of the post-test was 76.0. The student who passed the minimum criteria was $78 \%$. That is why it was considered successful-the activities of cycle two. Lecturer's activities such us; the lecturer asked the student to shadow the sentence, the lecturer asked the student to write down what they heard, the lecturer asked them to find the meaning of the word and the sentence that they heard, and the lecturer checked the answer. The students did the same things: they shadowed the sentence, wrote down what they heard, found the meaning of the words and sentence, and discussed the answer together. In cycle two, the students basically did the same things, but the students were more comfortable in the activities. They already know what to do and also practice a lot in listening. From those activities in cycle one and cycle two, we can conclude that the shadowing technique can be applied to improve the listening skill of the students.

\section{Discussion}

Good listening skills will be the foundation that guides a language learner to language skills (Nakanishi et al., 2019; Yudhiantara \& Saehu, 2017). Listening is an activity that includes listening to the sounds of language, identifying, observing, and reacting to the meanings contained in the reading material (Monica et al., 2017; Widyaningrum, 2015). Listening is a complex skill that requires sharp attention, concentration, attitude, mental activeness, intelligence, and assimilation and application of every idea (Puspayanti et al., 2013; Putra et al., 2018). Listening is not only listening but a process of interpreting and understanding the meaning contained. The stages in the listening process are listening, understanding, analyzing, evaluating, and finally absorbing and accepting the ideas, ideas, or content put forward by the speaker and arriving at the responding stage (Santosa \& Andrean, 2021; Yuanta, 2017). Listening requires special attention with a good and calm situation when listening activities take place. Listening is the ability to identify and understand what others are saying. Applying appropriate techniques in learning will improve students' listening skills (K. M. Lubis, 2013; Vu \& Shah, 2016).

The technique is a way that can be done to hold teaching and learning activities so that they run well (Barsih, 2016; Wicaksono et al., 2020). One variation of learning that can be used to learn Japanese is by using the shadowing technique. Shadowing is defined as headphones for hearing and repeating a sound (Omar \& Umehara, 2012; Wardhana, 2018). The shadowing approach is a listening learning method. In addition, shadowing turned out to be an exercise technique to beautify pronunciation. Shadowing refers to the way of practice in the form of listening to a sound and as much as possible without giving a pause, and students can follow the sound (Chiu et al., 2020; Wardhana, 2018). Activities that have a solid cognitive value because the learner must follow the speaker's words, pronounce them again clearly, and at the same time, the learner must, of course, listen so that the shadowing technique is feasible to be applied in learning and can improve students' listening skills. 


\section{CONCLUSION}

Shadowing could improve students' listening skills in the first-year students of Accounting Major in Triatma Mulya University. In the activities in cycle one, the lecturer let the students shadow the sentence without limitation time. The students felt afraid of making mistakes in process one because it was a new thing for them. In cycle two, the progress was better. The students already know what to do, and they can easily do the activities in shadowing

\section{REFERENCES}

Alam, S. K., \& Lestari, R. H. (2020). Pengembangan Kemampuan Bahasa Reseptif Anak Usia Dini dalam Memperkenalkan Bahasa Inggris melalui Flash Card. Jurnal Obsesi : Jurnal Pendidikan Anak Usia Dini, 4(1), 284. https://doi.org/10.31004/obsesi.v4i1.301

Alilateh, A., \& Widyantoro, A. (2019). The effectiveness of using multiple intelligence activities in listening comprehension and improving students' interest. LingTera, 6(2), 111-118. https://doi.org/10.21831/lt.v6i2.10625

Amiryousefi, M., \& Tavakoli, M. (2011). The Relationship between Test Anxiety, Motivation and MI and the TOEFL iBT Reading, Listening and Writing Scores. Procedia - Social and Behavioral Sciences, 15. https://doi.org/10.1016/j.sbspro.2011.03.075

Azar, A. S., \& Nasiri, H. (2014). Learners' Attitudes toward the Effectiveness of Mobile Assisted Language Learning (MALL) in L2 Listening Comprehension. Procedia - Social and Behavioral Sciences, 98. https://doi.org/10.1016/j.sbspro.2014.03.613

Barsih, B. (2016). Pengaruh Model Pembelajaran Cooperative Learning Teknik Inside Outside Circle Terhadap Hasil Belajar Siswa Bidang Studi IPS MI Darul Mujahidin. Muallimuna: Jurnal Madrasah Ibtidaiyah, 1(2). https://doi.org/10.31602/muallimuna.v1i2.382

Chen, Y., Mayall, H. J., York, C. S., \& Smith, T. J. (2019). Parental perception and English Learners' mobileassisted language learning: An ethnographic case study from a technology-based Funds of Knowledge approach. Learning, Culture, and Social Interaction, 22. https://doi.org/10.1016/j.lcsi.2019.100325

Chiu, H.-H. C., Angela, T., D’Souza, K., Cojocaru, D., Warnock, G., \& Blair, G. (2020). The Teacher-Learner Contract (TLC): An Objectives-Based Checklist for Surgical Shadowing. Journal of Surgical Education, 7(2). https://doi.org/10.1016/j.jsurg.2019.09.013

Coffelt, T. A., Grauman, D., \& Smith, F. L. M. (2019). Employers' Perspectives on Workplace Communication Skills: The Meaning of Communication Skills. Business and Professional Communication Quarterly, 82(4), 418-439. https://doi.org/10.1177/2329490619851119

Dashtestani, R. (2013). Implementing mobile-assisted language learning (MALL) in an EFL context: Iranian EFL teachers' perspectives on challenges and affordances. The JALT CALL Journal, 9(2), 149-168. https://doi.org/10.29140/jaltcall.v9n2.153

Dwi, N. M. L., Suwatra, I. I. W., \& Rasana, I. D. P. R. (2013). Pengaruh Model Pembelajaran Kooperatif Tipe Inside Outside Circle Terhadap Keterampilan Berbicara Bahasa Inggris Kelas IV SD Gugus X Kecamatan Buleleng. Mimbar PGSD Undiksha, 1(1). https://doi.org/10.23887/jjpgsd.v1i1.746

Gibbs, B., \& Hilburn, J. (2021). In the shadow of the base: Teaching war to the children of soldiers. The Journal of Social Studies Research. https://doi.org/10.1016/j.jssr.2021.09.003

Gjems, L. (2013). Teaching in ECE: Promoting children's language learning and cooperation on knowledge construction in everyday conversations in kindergarten. Teaching and Teacher Education, 29(1), 39-45. https://doi.org/10.1016/j.tate.2012.08.008

Haji, S. A., Moluayonge, G. E., \& Park, I. (2017). Teachers' use of information and communications technology in education: Cameroon secondary schools perspectives. Turkish Online Journal of Educational Technology, 2017(November Special Issue IETC), 671-679.

Jafari, K., \& Hashim, F. (2012). The effects of using advance organizers on improving EFL learners' listening comprehension: A mixed-method study. The system, 40(2). https://doi.org/10.1016/j.system.2012.04.009

Kaplan, D. E. (2018). Piagetian Theory in Online Teacher Education. Scientific Research Publishing, 9(6). https://doi.org/10.4236/ce.2018.96061

Karimi, P., \& Sanavi, R. V. (2014). Analyzing English Language Learning Needs among Students in Aviation Training Program. Procedia - Social and Behavioral Sciences, 98. https://doi.org/10.1016/j.sbspro.2014.03.491

Khotimah, K., Widiati, U., Mustofa, M., \& Faruq Ubaidillah, M. (2019). Autonomous English learning: Teachers' and students' perceptions. Indonesian Journal of Applied Linguistics, 9(2), 371-381. 
https://doi.org/10.17509/ijal.v9i2.20234

Kurniawati, K. R. A., Budiyono, \& Saputro, D. R. S. (2017). Penerapan Model Pembelajaran Kooperatif Tipe Jigsaw Dan Numbered Heads Together Ditinjau Dari Kecerdasan Interpersonal Siswa Pada Pokok Bahasan Bangun Ruang Sisi Datar. Jurnal Pendidikan Matematika, 11(1). https://doi.org/10.22342/jpm.11.1.3948.15-28

Le, C. N. N., \& Miller, J. (2020). A corpus-based list of commonly used English medical morphemes for students learning English for specific purposes. English for Specific Purposes, 58. https://doi.org/10.1016/j.esp.2020.01.004

Lestar, W. (2021). Pengembangan Modul Pembelajaran Bahasa Inggris Berbasis Andragogi Pada Program Studi Pendidikan Biologi di Universitas Muhammadiyah Palembang. Edunesia : Jurnal Ilmiah Pendidikan, 2(1), 171-177. https://doi.org/10.51276/edu.v2i1.114

Liang, Y., Zheng, T., \& Wang, M. (2011). English audio-visual teaching mode and its teaching environment construction - Henan Institute of Science and Technology as the example. 2011 International Conference on Multimedia Technology, 3050-3053. https://doi.org/10.1109/ICMT.2011.6001924

Liu, H., \& Sammons, P. (2021). Teaching in the shadow: Explorations of teachers' professional identities in private tutoring institutions in China. International Journal of Educational Research Open, 2(2). https://doi.org/10.1016/j.ijedro.2021.100071

Liu, J., \& Bray, M. (2020). Private Subtractory Tutoring: The Negative Impact of Shadow Education on Public Schooling in Myanmar. International Journal of Educational Development, 76. https://doi.org//10.1016/j.ijedudev.2020.102213

Lubis, A. H. (2018). Integrasi TIK Dalam Pengajaran Bahasa Inggris Di Indonesia Abad Ke-21: Mitos Dan Realita. Cakrawala Pendidikan, 37(1), 11-21. https://journal.uny.ac.id/index.php/cp/article/view/16738/pdf.

Lubis, K. M. (2013). Peningkatan Aktivitas Pembelajaran Hidrosfer Dan Dampaknya Terhadap Kehidupan Melalui Tindakan Guru Inovatif Pada Kelas X Di Sma Negeri 1 Semarang. Jurnal Geografi: Media Informasi Pengembangan Dan Profesi Kegeografian, 10(2), 189-202. https://doi.org/10.15294/jg.v10i2.8062

Megawati. (2016). Kesulitan Mahasiswa Dalam Mencapai Pembelajaran Bahasa Inggris Secara Efektif. Jurnal Pedagogia, 5(2). https://doi.org/10.21070/pedagogia.v5i2.246

Monica, S., Pribady, H., \& Sunarsih, E. (2017). Peningkatan Keterampilan Menyimak Cerita Pendek dengan Model Cooperativesomatic Auditory Visualization Intellectualy (SAVI) pada Siswa Kelas VII F SMP Negeri 3 Singkawang Tahun Pelajaran 2015/2016. JP-BSI (Jurnal Pendidikan Bahasa Dan Sastra Indonesia), 2(1). https://doi.org/10.26737/jp-bsi.v2i1.229

Muhammed, A. A. (2014). The Impact of Mobiles on Language Learning on the Part of English Foreign Language (EFL) University Students. Procedia - Social and Behavioral Sciences, 136. https://doi.org/10.1016/j.sbspro.2014.05.297

Mulyanah, Ishak, \& Iqbal. (2018). Penerapan Metode Total Physical Response (TPR) dalam Penguasaan Kosakata Bahasa Inggris Sekolah Dasar (SD). Jurnal Pendidikan Sekolah Dasar, 4. https://doi.org/10.30870/jpsd.v4i2.3855

Naghdipour, B. (2021). English writing pedagogy at the crossroads: The case of Oman. Journal of Second Language Writing, 52. https://doi.org/10.1016/j.jslw.2021.100815

Nakanishi, J., Sumioka, H., \& Ishiguro, H. (2019). A huggable communication medium can provide sustained listening support for special needs students in a classroom. Computers in Human Behavior, 93. https://doi.org/10.1016/j.chb.2018.10.008

Omar, H., \& Umehara, M. (2012). Using a Shadowing Technique to Improve English Pronunciation Deficient Adult Japanese Learners: An Action Research on Expatriate Japanese Adult Learners. The Journal of Asia TEFL,

$7(2)$. http://journal.asiatefl.org/main/main.php?inx_journals=24\&inx_contents=173\&main=1\&sub=2\&submode =3\&PageMode=JournalView\&s_title=Using_A_Shadowing_Technique_to_Improve_English_Pronunciati on_Deficient_Adult_Japanese_Learners_An_Action_Research_on_Expatriate_Japanese_Adult_Learners

Pratiwi, K. Y., Rasana, I. D. P. R., \& Pudjawan, K. (2018). Pengaruh Model Pembelajaran Teams Games Tournament ( Tgt ) Terhadap Penguasaan Kosakata Bahasa Inggris Siswa Kelas Iv Sd Gugus Iv Kecamatan Tabanan. JJPGSD, 1(1). https://doi.org/10.23887/jjpgsd.v1i1.790

Puspayanti, I. G. A. R., Darsana, I. W., \& Ganing, N. N. (2013). Pengaruh Pendekatan Savi Terhadap Keterampilan Menyimak Pada Mata Pelajaran Bahasa Indonesia Gugus Letkol Wisnu Kecamatan Denpasar Utara. Mimbar PGSD Undiksha, 1(1). https://doi.org/10.23887/jjpgsd.v1i1.1256

Putra, I. N. A., Jampel, I. N., \& Sudatha, I. G. W. (2018). Pengembangan Multimedia Flashcard Untuk Meningkatkan Kemampuan Menyimak Di TK Negeri Pembina Singaraja. Edutech Undiksha, 6(1), 32. https://doi.org/10.23887/jeu.v6i1.20260

Rosmiati, M. (2019). Animasi Interaktif Sebagai Media Pembelajaran Bahasa Inggris Menggunakan Metode 
ADDIE. Paradigma: Jurnal Komputer Dan Informatika Univiersitas Bina Sarana Informatika, 21(2). https://doi.org/10.31294/p.v21i2.6019

Santosa, S., \& Andrean, S. (2021). Pengembangan dan Pembinaan Karakter Siswa dengan Mengoptimalkan Peran Guru Sebagai Contextual Idol di Sekolah Dasar. Jurnal Basicedu, 5(2), 952-957. https://doi.org/10.31004/basicedu.v5i2.849

Sihotang. (2019). Optimalisasi Penggunaan Google Class Room Dalam Peningkatan Minat Belajar Bahasa Inggris Siswa Di Era Revolusi Industri 4.0 (Studi Kasus Di SMK Swasta Arina Sidikalang). Jurnal Teknologi Dan Ilmu Kesehatan, 1(1). http://e-journal.sari-mutiara.ac.id/index.php/tekesnos/article/view/981.

Surjono, J. (2016). Pengembangan Multimedia Pembelajaran Bahasa Inggris Untuk Pembelajaran Teks Recount Di Mtsn II Yogyakarta. Jurnal Inovasi Teknologi Pendidikan, 3(1), $25-39$. https://doi.org/10.21831/tp.v3i1.8287

Tanihardjo, J. (2016). The Analysis of Students' English Competence in the Grammar Section in the Paper-Based TOEFL: A Case Study at English Department in Bunda Mulia University. Journal of English Language \& Culture, 6(1). https://doi.org/10.30813/jelc.v6i1.270

Tjakradidjaja, F. A., Prabandari, Y. S., Prihatiningsih, T. S., \& Harsono, H. (2016). The role of teacher in medical student self-directed learning process. Journal of Education and Learning (EduLearn), 10(1), 78-84. https://doi.org/10.11591/edulearn.v10i1.2992

Tum, D. O., \& Kunt, N. (2021). Language learning under the shadow of conflict: Teachers' beliefs about teaching the language of the "other." Teaching and Teacher Education, 107. https://doi.org/10.1016/j.tate.2021.103485

Voorhees, T. T., \& Vorobel, O. (2021). Integrating Qualitative Research into the Community College Linguistics Course: An Autoethnographic Inquiry. International Journal of Educational Research Open, 2. https://doi.org/10.1016/j.ijedro.2021.100053

Vu, H. Y., \& Shah, M. (2016). Vietnamese students' self-direction in learning English listening skills. Asian Englishes, 18(1), 53-66. https://doi.org/10.1080/13488678.2015.1136104

Wardhana, I. G. N. P. (2018). Teknik Shadowing Meningkatkan Kemampuan Mahasiswa Berbicara Bahasa $\begin{array}{lllll}\text { Inggris. Jurnal Linguistik Dan } & \text { Sastra, } & \text { https://e- }\end{array}$ journal.unmas.ac.id/index.php/sphota/article/view/1135

Wicaksono, P. N., Kusuma, I. J., Festiawan, R., Widanita, N., \& Anggraeni, D. (2020). Evaluasi penerapan pendekatan saintifik pada pembelajaran pendidikan jasmani materi teknik dasar passing sepak bola. Jurnal Pendidikan Jasmani Indonesia, 16(1), 41-54. https://doi.org/10.21831/jpji.v16i1.29774.

Widyaningrum, H. K. (2015). Penggunaan Media Audio untuk Meningkatkan Kemampuan Menyimak Dongeng Anak pada Siswa Kelas IV Sekolah Dasar. Premiere Educandum Jurnal Pendidikan Dasar Dan Pembelajaran, 5(2). https://doi.org/10.25273/pe.v5i02.284

Wungguli, D., \& Yahya, L. (2020). Pengaruh Penggunaan Media Berbasis Information and Communication Technology (ICT) terhadap Hasil Belajar Siswa pada Materi Dimensi Tiga. Jambura Journal of Mathematics Education, 1(1), 41-47. https://doi.org/10.34312/jmathedu.v1i1.5376

Yuanta, F. (2017). Pengembangan Media Audio Visual Mata Pelajaran Bahasa Indonesia Untuk Sekolah Dasar. Ibriez: Jurnal Kependidikan Dasar Islam Berbasis Sains, 2(2), 59-70. https://doi.org/10.21154/ibriez.v2i2.36

Yudhiantara, R. A., \& Saehu, A. (2017). Mobile-Assisted Language Learning (MALL) in Indonesian Islamic Higher Education. IJELTAL (Indonesian Journal of English Language Teaching and Applied Linguistics), 2(1), 21-31. https://doi.org/10.21093/ijeltal.v2i1.52 